MILICA TAPAVIČKI-ILIĆ

Institute of Archaeology

Belgrade, Serbia

E-mail: mtapavic@sbb.rs

MARIJA ŠEGAN-RADONJIĆ

Mathematical Institute SANU

Belgrade, Serbia

E-mail:msegan@mi.sanu.ac.rs
Received: October $30^{\text {th }} 2021$

Accepted: November $20^{\text {th }} 2021$

Original research article

902/904:004.65(497.11)"2019/2020"

COBISS.SR-ID 55186953

https://doi.org/10.18485/arhe_apn.2021.17.7

\title{
METHODS AND CAPACITY IN ARCHAEOLOGICAL DATA MANAGEMENT IN SERBIA
}

\begin{abstract}
Over the past year and due to the COVID-19 pandemic, the entire world has witnessed inequalities across borders and societies. They also include access to archaeological resources, both physical and digital. Both archaeological data creators and users have spent a lot of time working from their homes, away from artefact collections and research data. However, this was the perfect moment to understand the importance of making data freely and openly available, both nationally and internationally. The authors of this paper selected databases from various institutions in Serbia responsible for the preservation and protection of cultural heritage, in order to understand their policies regarding accessibility and usage of the data they hold. It needs to be seen whether it is possible to access digital objects, if access is open for all users or it requires a certain hierarchical access, and what the policy of usage, re-usage and distribution is.
\end{abstract}

\section{KEYWORDS: DATA, DATA MANAGEMENT, SERBIA, ARCHAEOLOGY, DATABASE.}

\section{INTRODUCTION}

Over the past year and due to the COVID-19 pandemic, the entire world has witnessed inequalities across borders and societies. They also include access to archaeological resources, both physical and digital. Both archaeological data creators and users have spent a lot of time working from their homes, away from artefact collections and research data. However, this was the perfect moment to understand the importance of making data freely and openly available, both nationally and internationally.

This is why the authors of this paper chose to select databases from various institutions responsible for the preservation and protection of cultural heritage, in order to understand their policies regarding accessibility and usage of the data they hold. This will be done by simple visits to various web-sites or databases. They intend to check on the volume and content, but also to highlight the importance of the offered archaeological heritage. In addition, the authors will estimate whether the heritage has adequately been classified and described and also check whether data is available in foreign languages.

It needs to be seen whether it is possible to access digital objects (documents and the accompanying metadata), whether access is open for all users or if it requires a certain hierarchical access, and what the policy of usage, re-usage and distribution is. It remains to be seen whether there are public APIs and whether it is possible to collect data through an API. In cases where there is a public API, one needs to check whether the datasets are interoperable or messy, requiring data cleaning. 




Fig. 1 - Data sets about immobile cultural heritage published at the Portal of open data in JSON format (top) and refined data set about archaeological sites of extreme importance downloaded from the Portal in CSV format (bottom).

After having visited a number of web-sites, the authors hope to collect enough data to make a satisfactory conclusion regarding the accessibility and usage of Serbian archaeological databases.

\section{OPEN DATA - REGULATIONS IN SERBIA}

In 2003, the European Union issued the Directive on the re-use of public sector information, which was subsequently upgraded in 2013 (Direc- tive 2003/98/EC and Directive 2013/37/EU). Following the example of the European Union, the Serbian government recognised the importance of the re-use of data owned by its public institutions and highlighted its strategic determination to open them for the public. This is why, among others, the Government based its development programme of the electronic administration on the principles of the aforementioned Directive, on the G8 Open Data Charter (see G8 Open Data Charter), as well as on the guidelines of the international initiative 


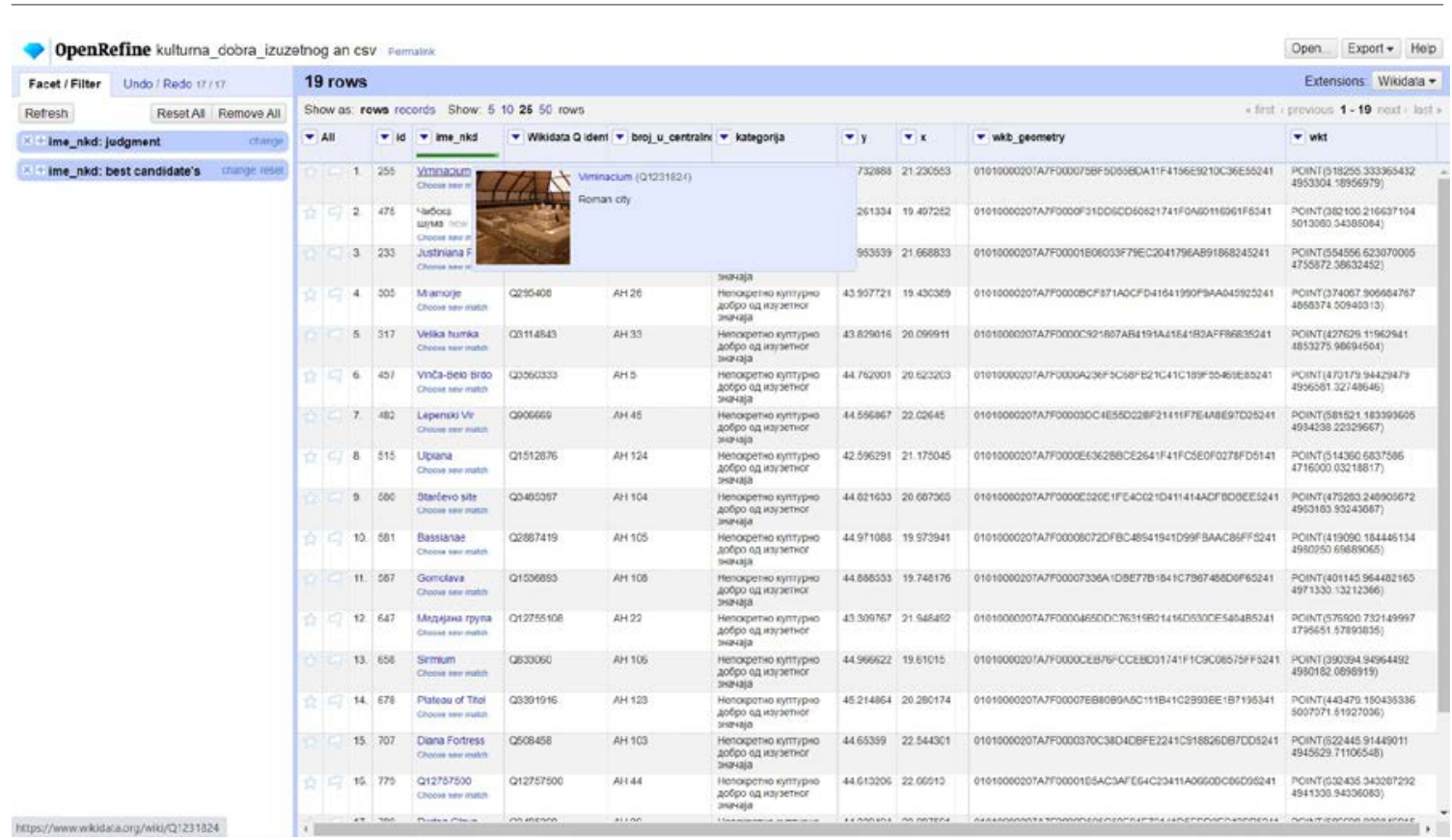

Fig. 2 - Cleaning and connecting the downloaded data set about cultural heritage of extreme importance from the Wikidata open knowledge base and creating a column with a Wikidata Q identificatory with the OpenRefine tool (see OpenRefine).

Open Government Partnership (Partnerstvo za otvorenu upravu). Serbia became a member of the Open Government Partnership in 2012 (see POU Serbia). In 2015, in its Strategy for development of electronic administration (Strategija za razvoj elektronske uprave), it included special chapters related to open data (Službeni glasnik 107/2015). After that, in 2016, it formed a Working group for open data (Radna grupa za otvorene podatke). However, only in 2018 did it actually begin with the legal regulations of open data by issuing the Law on electronic administration (Zakon o elektronskoj upravi, see Službeni glasnik 27/2018). At the same time, the National portal of open data (Portal otvorenih podataka, see Službeni glasnik 104/2018) also included some of the European regulations into the Serbian legal system (Церовић 2019: 64). At the time of this paper being written, Serbia was in 41 st place on the list of 94 countries in which open administration has been introduced and developed (Global Open Data Index; Službeni glasnik 85/2020).

The Law on electronic administration (Zakon o elektronskoj upravi) introduced an obligation for state bodies to publish data that is within the scoop of their competence on the Portal of Open Data (Portal otvorenih podataka) in a way that allows for it to be easily searched and re-used (Službeni glasnik 27/2018). Open data includes data "that is available for re-use, along with metadata, in a machine-readable open form". Thus, it is made available to anyone to use it "in any way, for any purpose, without copyright restrictions and control mechanisms" (Церовић 2019: 19). The only obligation of the user is to state the source of the data and to record possible changes (Službeni glasnik 104/2018). This data, however, is not personal data, i.e. information related to specific persons, the processing of which is regulated by the Law on personal data protection (Zakon o zaštiti podataka o ličnosti) (Službeni glasnik 87/2018), nor data protected by copyright and/or property rights, again regulated by the Law of copyright and related rights (Zakon o autorskim i srodnim pravima) (Церовић 2019: 20). It should be borne in mind that there are numerous categorisations of open data. Therefore, further in the paper the emphasis is put on: 1) data on cultural content, 

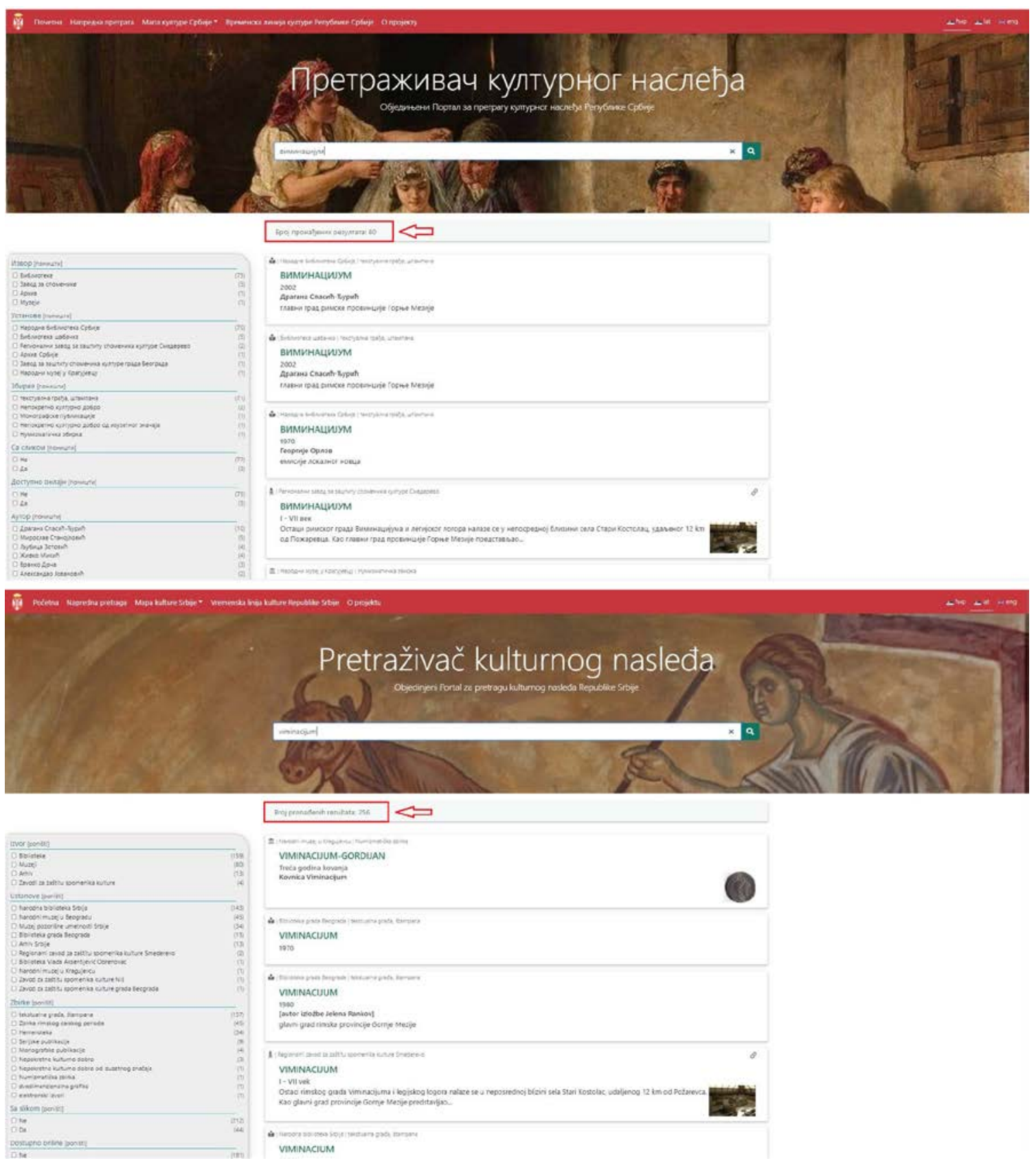

Fig. 3 - Search results by using the key word „виминацијум” (top) and „viminacijum” (bottom) in the Browser of cultural heritage (Pretraživač kulturnog nasleđa, accessed July 20th, 2021).

primarily on archaeological heritage and 2) data collected during research in social sciences, primarily in archaeology. ${ }^{1}$

1 In Serbian archaeology, the concept of archaeological heritage includes physical heritage (e.g. archaeological sites and archaeological finds), archaeological excavations/research and results (e.g. archaeological documentation), as well as heritage management (e.g. alienation and protection). Archaeological heritage, like archaeological
Data about cultural heritage offers an overview of cultural items and the heritage of a coun-

sites, can be categorised as a cultural asset, determined by the Government of the Republic of Serbia and the authorised Institute for the protection of cultural monuments. Furthermore, archaeological research/excavations, as well as managing cultural heritage, are legally regulated in the Republic of Serbia and they are conducted within state institutions and organs (Šegan-Radonjić, Tapavički-Ilić 2021). 

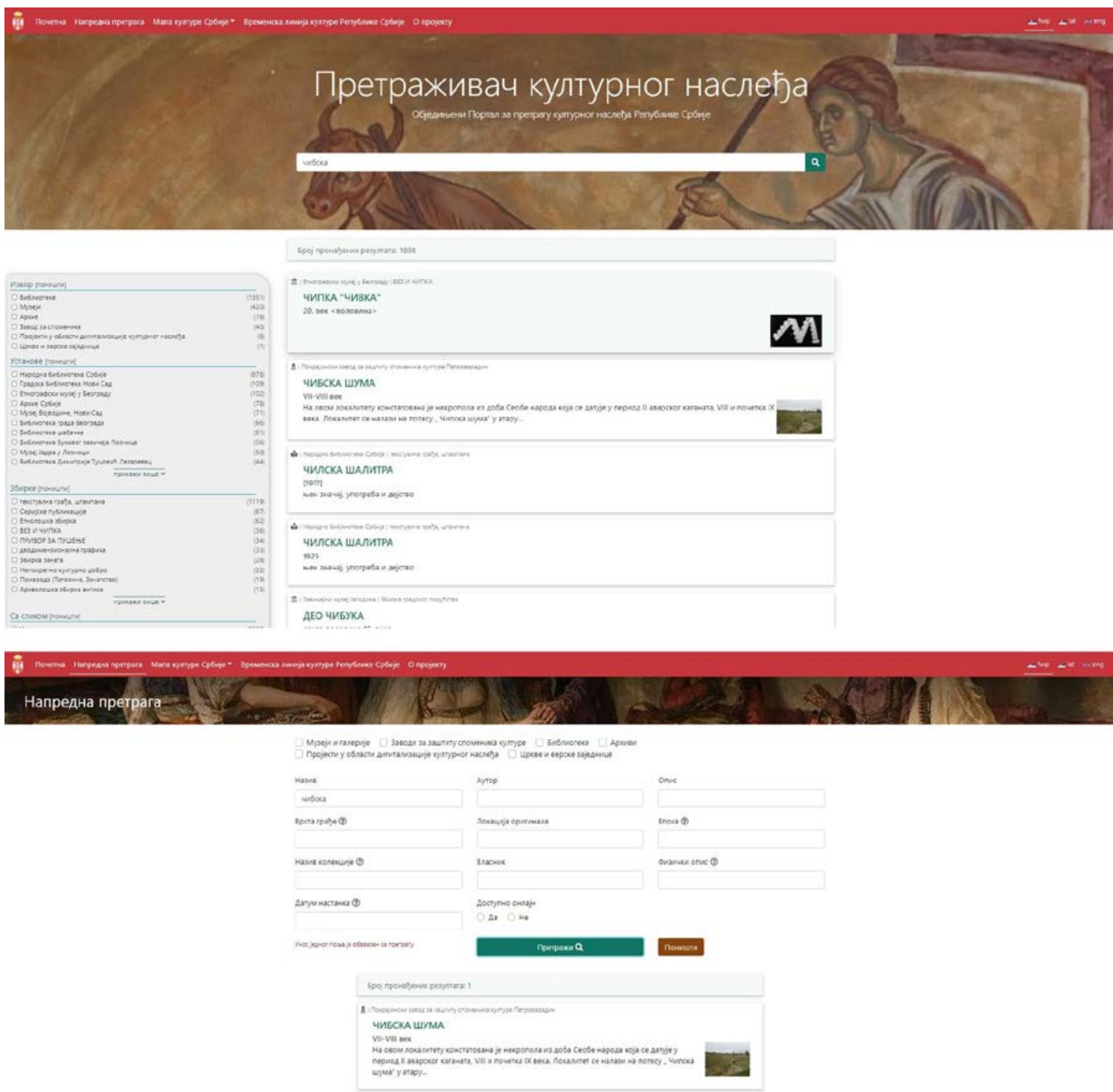

Fig. 4 - Search results of the word „čibska“ in the Browser of cultural heritage (Pretraživač kulturnog nasleđa, accessed July 20th, 2021).

try and is mostly owned by a responsible ministry (i.e. the Ministry of Culture and Information of the Republic of Serbia) or institutions for protection (i.e. archives, libraries, institutes for protection of cultural monuments, museums and other subjects in culture) (Церовић 2019: 20). Before 2020, in the Republic of Serbia and within the domain of culture, the principle of openness was not mentioned within laws and legal paragraphs. Only within the appendix of the Law on culture (Zakon o kulturi), issued in 2020, within the principles of cultural development, were the principle of openness and accessibility of cultural content added, but without a wider explanation (Službeni glasnik 72/2009, 6/2020). A detailed explanation was only given about the concept of accessibility to cultural content in an electronic form. If it is publicly accessible, it can also be publicly accessed in an electronic form, in a way that does not break regulations regarding protection of intellectual property and privacy (Službeni glasnik 6/2020; Smernice za digitalizaciju kulturnog nasleđa RS 2017). Public access mostly includes access to a digital object and the downloading of 


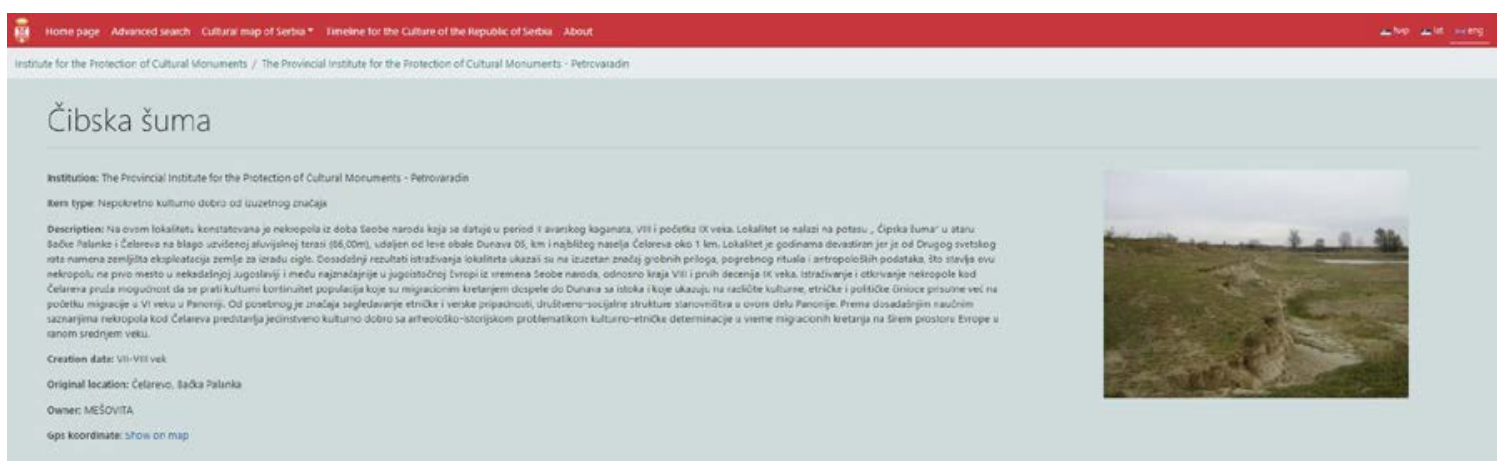

Fig. 5 - Basic descriptive metadata about the digital object Čibska šuma in the Browser of cultural heritage (Pretraživač kulturnog nasleđa, accessed July 20th, 2021).

metadata from an adequate information system, for example from the national Aggregator of Cultural Heritage (see Pretraživač kulturnog nasleđa) or the national Portal of Open Data (see Portal otvorenih podataka) (Službeni glasnik 76/2018).

When it comes to primary data collected through research that is fully or partly funded from the budget of the Republic of Serbia, the Government of the Republic of Serbia adopted recommendations of the European Commission (see Berlin Declaration 2003; Guidelines to the Rules on Open Access 2017) and introduced the principles of open science in its strategies and legal acts. Among others, these include access to scientific publications and open access to primary research data (Službeni glasnik 25/2016; Službeni glasnik 49/2019; Službeni glasnik 10/2021). Furthermore, in 2018, aiming to achieve the greatest possible efficiency in implementing the principles, it established the national Platform for Open Science (Platforma za otvorenu nauku) and gave a recommendation to universities and scientific institutions in Serbia to adopt specific repositories that are in accordance with the Platform. The repositories are intended for scientists to upload their data and secure their safe keeping and re-usage according to the FAIR standards ${ }^{2}$ (Platforma za otvorenu nauku 2018). Usage and re-usage implies the right of every internet user to freely download, modify, keep and distribute data, while

2 About FAIR (Findable, Accessible, Interoperable, Reusable) principles see Smederevac 2020:54-55. respecting corresponding copyrights and the obligation of stating the source of the information. However, this does not include data marked as confidential or confidential business data.

At the time of this paper being written, on the official page of the national Portal of Open Science (Portal otvorene nauke) there were 35 national/thematic/institutional repositories, some of them showing several initiatives of data open access (see Portal za otvorenu nauku). For example, the National Repository of Doctoral Theses in Serbia (Nacionalni repozitorijum disertacija $u$ Srbiji-NaRDuS) gives access to doctoral theses (among others, in the field of archaeology) defended at all of the universities in Serbia and enables access to metadata (see NaRDuS). Depositing primary research data into specific repositories also became part of conducting projects within the national programmes of the Fund for Science of the Republic of Serbia (Fond za nauku Republike

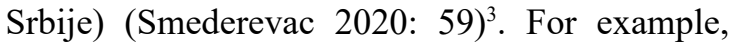
participants of the Fund programmes are obliged to state the method of collecting, keeping and depositing research data in order to make them further accessible. ${ }^{4}$ In order to manage the data,

3 Fund for science of the Republic of Serbia (Fond za nauku Republike Srbije) is a state authority established in March 2019. It funds projects in the field of scientific and technological development through public calls (see Fond za nauku RS). Until July 2021, of the total of 177 projects approved for funding, the Fund supported two projects in the field of archaeology.

4 Similar to the obligation of participants who take part in the funding programme of the EU for re- 


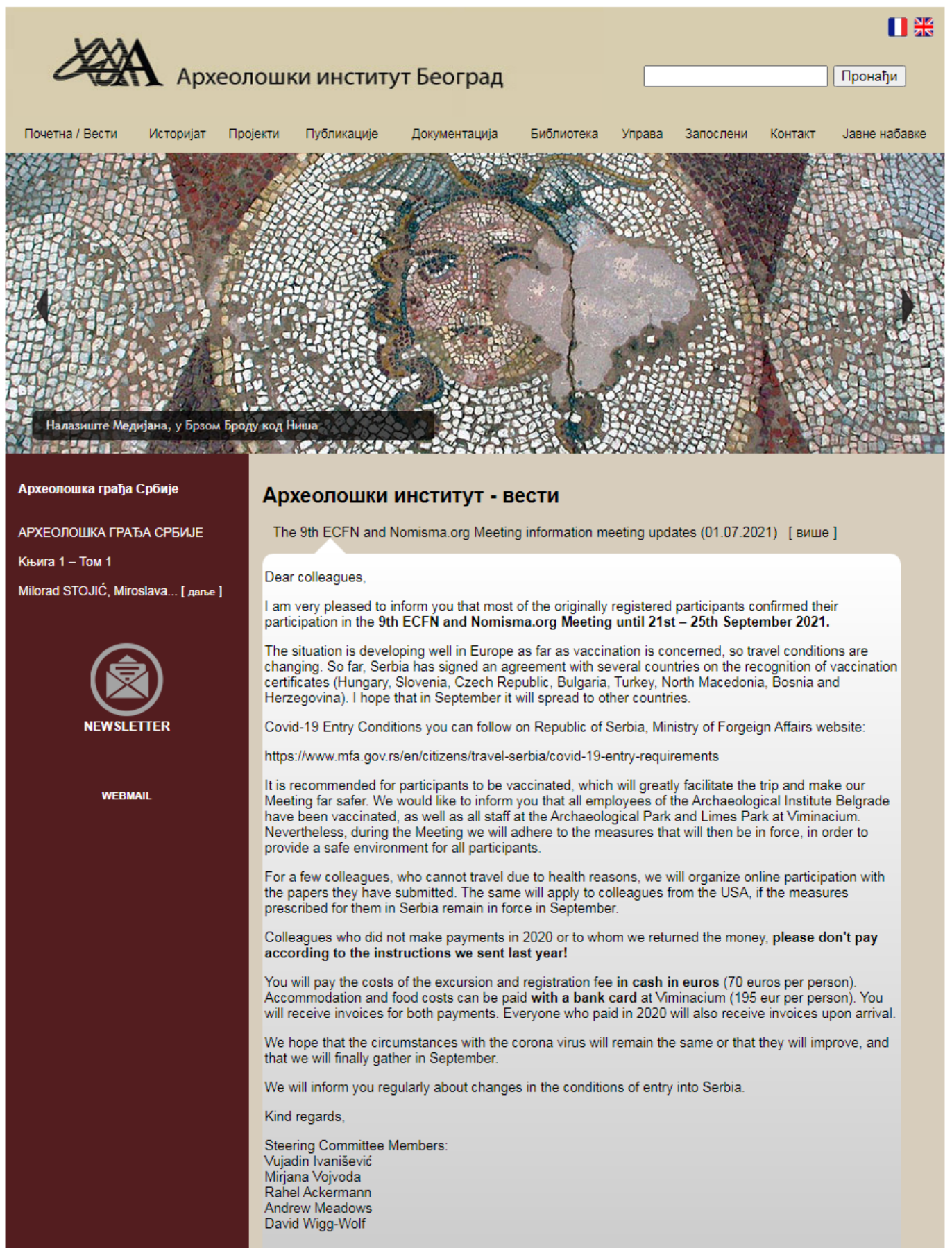

Fig. 6 - Homepage of the Institute of Archaeology (accessed July 6th, 2021).

they are advised to use one of the already existing open research infrastructures, such as Računarski centar Univerziteta u Beogradu (see RCUB) and Data centar Srbije za društvene nauke (see $D C S$ ),

search and innovation, Horizon 2020, who need to submit their Data Management Plan (DMG). but also develop their own infrastructure in accordance with the Platform for Open Science (Platforma za otvorenu nauku). 


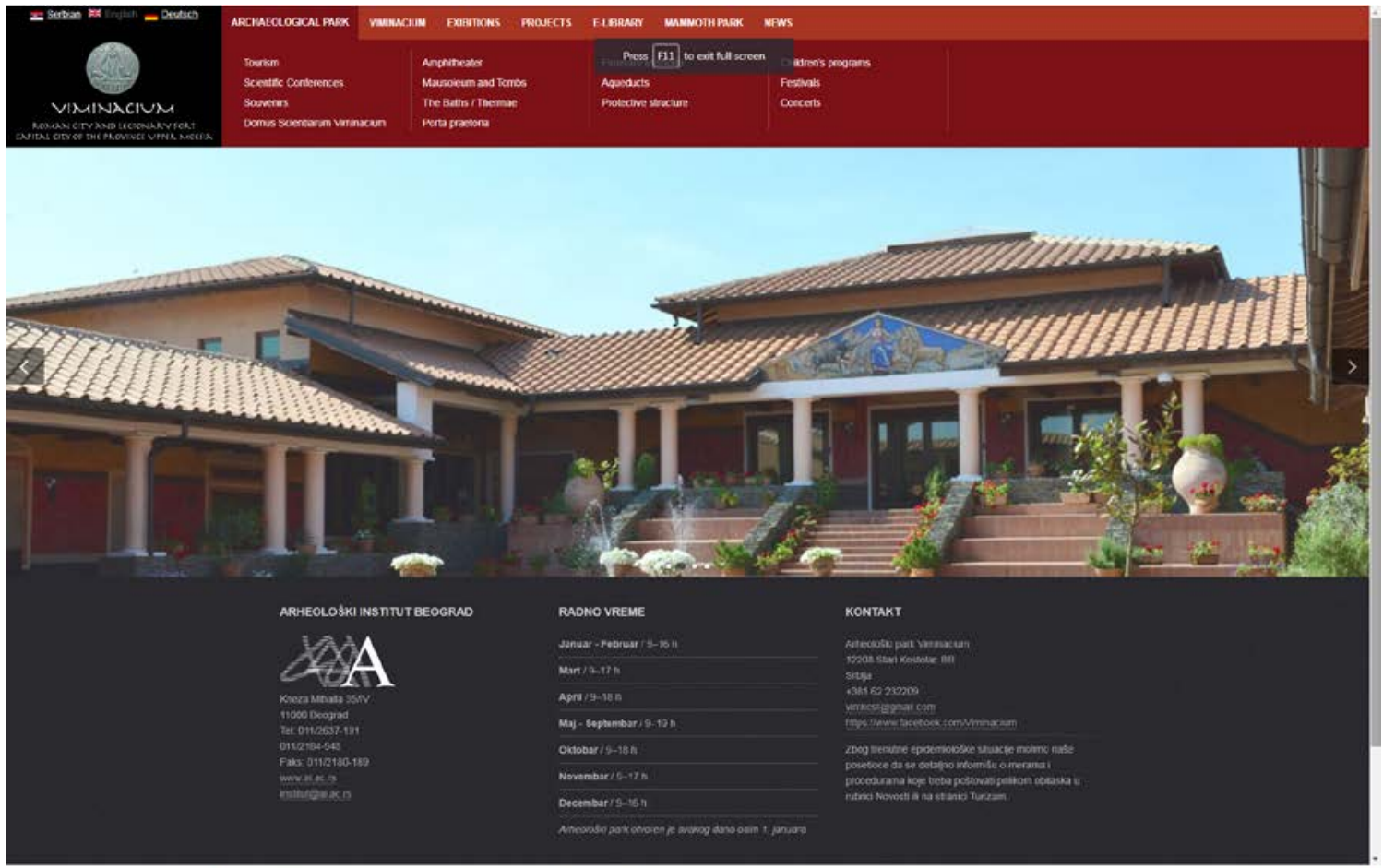

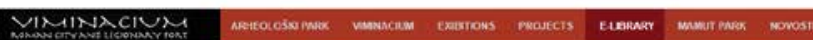

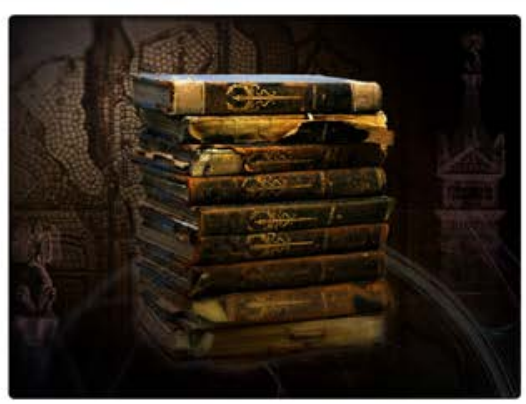

inver

Tourian

surenies

The Masuscleum and the Cameteries

The Baths

The Porta Pratocis

Funeray Menoria

Aquedioct

Protective strucaure

Mamut park

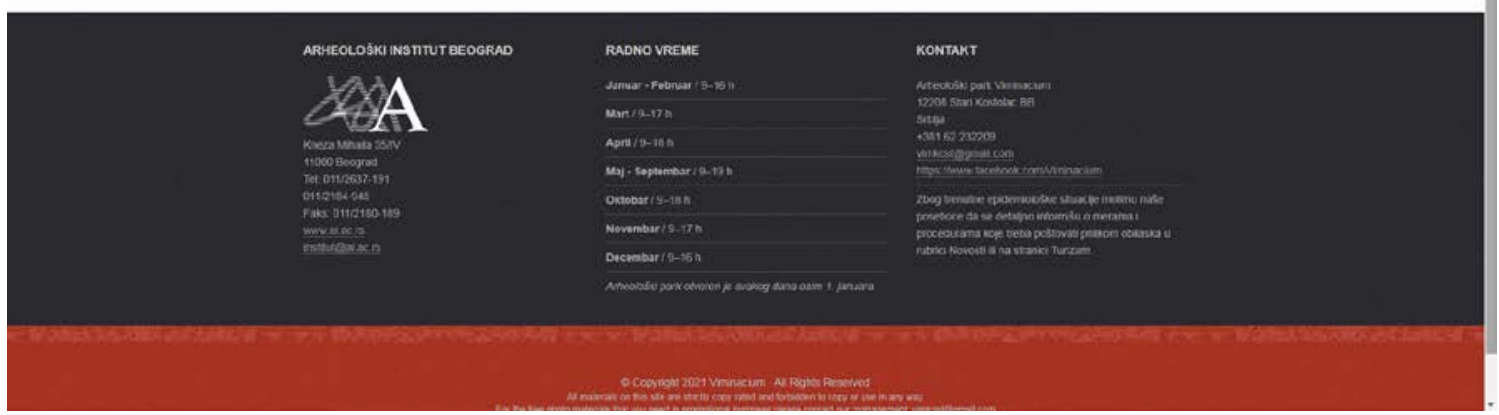

Fig. 7 - Website of the archaeological site Viminacium (top) and its E-library (bottom) (accessed August 12th, 2021). 


\section{PUBLIC ACCESS TO CULTUR- AL HERITAGE IN ELECTRONIC FORM - THE PORTAL OF OPEN DATA AND CULTURAL HERITAGE BROWSER}

The national Portal of Open Data (Portal otvorenih podataka) was modelled on similar initiatives in the USA (see data.gov) and the EU (see data.europa.eu). It represents a repository in which state authorities of the Republic of Serbia are obliged to announce sets of open data that are in their possession (Službeni glasnik 104/2018). This data needs to be published in a raw and machine-legible form i.e. in accordance with the prescribed List of Interoperable Standards (see Lista standarda interoperabilnosti 2.1). It can be used by any physical or legal entity, both for commercial and non-commercial purposes, however with the obligation to state the source (i.e. the state authority that made the data accessible) and any possible changes.

Up to the middle of 2021, within the Portal of Open Data (Portal otvorenih podataka), the Ministry of Culture and Information of the Republic of Serbia has shared thirteen data sets, among which there were three metadatabases about immovable cultural heritage in Serbia. These databases can be downloaded in either JSON or CSV format, even without registration on the Portal and also without any fees (Fig. 1). The data is provided in both $\mathrm{Cy}-$ rillic and Latin script. As an example, the database about immovable cultural heritage of extreme importance contains metadata about 213 cultural objects, among which there are also nineteen archaeological sites (Fig. 2). At this moment, the database is not linked to other knowledge bases (e.g. Wikidata or VIAF) ${ }^{5}$, but the user can do this on his/her own and according to his/her needs. In the case of downloading data sets through API, authentication

5 Wikidata is a free and open internet knowledge base used as a storage for structured data of sisterly Wikimedia like Wikipedia. VIAF (Virtual International Authority File) is a free internet service that links normative records of different libraries (see VIAF). is necessary, meaning that one first needs to create an account on the Portal, generate the API secret code and then download data by using specific programme tools. Since within this section the earliest data sets were shared only recently, actually in 2019 , it is presumed that the amount of shared data will grow in the period to come.

The national aggregator Pretraživač kulturnog nasleđa was modelled on the EU project - EUROPEANA - in cooperation with the National Library of Finland and with the support of the Microsoft Company Serbia (Objedinjeni portal 2019). It represents a system for searching all of the accessible data about cultural heritage collected from information systems that are owned by the responsible Ministry, actually institutions for protection (archives, libraries, institutes for the protection of cultural monuments and other subjects in culture) (Službeni glasnik 76/2018; Вуликић 2020). It secured the visibility and accessibility of information about cultural heritage kept at the institutions for protection.

Up to July 2021, within Pretraživač, one archive, eighteen libraries, sixty-four museums, thirteen institutes for the protection of cultural monuments and five church and religious communities have made their metadata about chosen digital objects in their possession digitally accessible. The user can search them in Serbian or English, by using a key-word or by typing a specific element (e.g. name of the author or location) into the form for an advanced search. In both cases, the browser shows a list of accessible objects with their metadata containing the specific term. One should bear in mind that browsing with a key-word shows different results for the same term, but written in the two different scripts. For example, if the user is interested in the popular archaeological site Viminacium, by typing the key-word in Cyrillic script (“виминацијум”), he/ she receives 80 search results, while in the Latin script ("Viminacium") 256 results are obtained (Fig. 3). Furthermore, if the user is interested in a lesser known site, for example Čibska šuma, a 


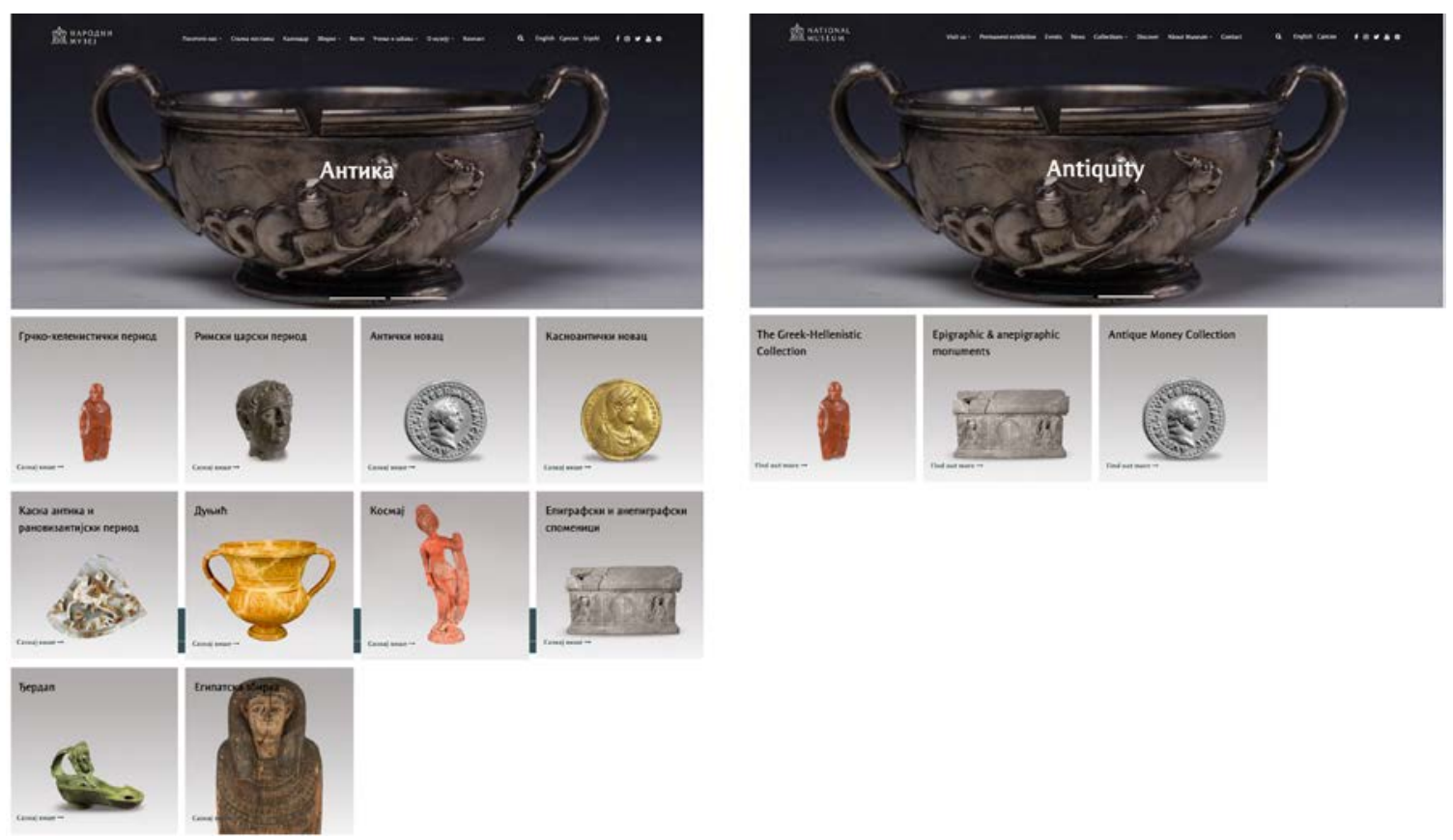

Fig. 8 - Data about „Collections“ (,Zbirke“) as displayed on the website of the National museum in Belgrade are offered in Serbian (left) and English language (right) (accessed August 13th, 2021).

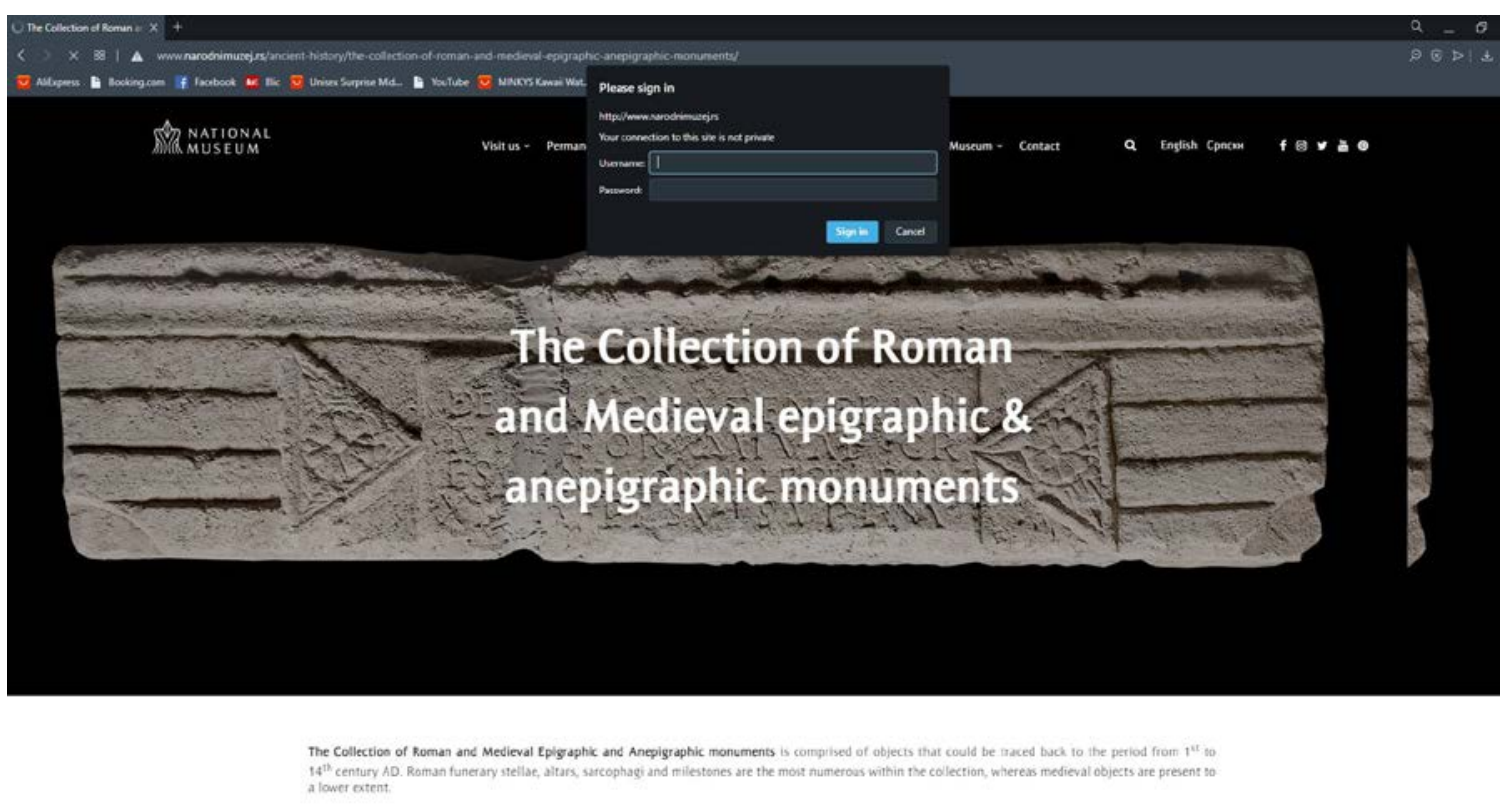

Fig. 9 - Accessing the English version of „Epigraphic and anepigraphic monuments“ of the National museum in Belgrade is possible only with a user-name and a password (accessed August 13th, 2021).

search with the key-word "čibska" does not give a satisfactory result and this is why it is better to use the form of advanced search (Fig. 4). By choosing specific search results (i.e. digital objects), the user gains access to basic metadata about the chosen object, such as name, place and year of creation (Fig. 5). Such a set of data is not opened, meaning that the user cannot download and re-use it. It only gives basic information about the object and offers an insight into the collection of the specific institution for protection. 
PUBLIC ACCESS TO PRIMARY RESEARCH DATA IN INSTITUTIONAL REPOSITORIES

The first website that was visited was that of the Institute of Archaeology (Arheološki institut http:// www.ai.ac.rs). ${ }^{6}$ (Fig. 6) The content of this site includes its homepage with a subsection for news, history of the institution, a list of projects and a list of its publications, the documentation sector, library, its management team and the list of employees. For the time being, the site is usable for Serbian speaking users only. Regarding archaeological material, the homepage of this site displays five images, four of which show archaeological structures and finds. Accompanying each image there is a brief description of what is depicted. When one moves from the homepage through all the further sections, there are still the same five images shown repeatedly. However, since the Institute of Archaeology is a research institution and not one that deals with protection or storage of archaeological material, this can easily be understood. On the other hand, the great value of the Institute's website lies in its e-library, which is to be found in the section named "Publications". This particular link leads its visitors to the website http://viminacium.org.rs/ebiblioteka/ ${ }^{7}$ (Fig. 7, bottom).

The e-library of the Viminacium website offers access to a large number of publications issued by the Institute of Archaeology, both periodicals and monographs, and even to a limited number of relevant newspapers releases. One can say that in such a way, access to archaeological material is made possible, under the condition that the user knows exactly which bibliographic unit he/she is looking for.

If the website of the archaeological site of Viminacium is observed as a whole (http://viminacium.org.rs/arheoloski-park//8 ${ }^{8}$ (Fig. 7, top), it

6 http://www.ai.ac.rs (accessed on July $6^{\text {th }}, 2021$ ).

$7 \mathrm{http}$ //viminacium.org.rs/e-biblioteka/ (accessed on July $6^{\text {th, }}$ 2021).

$8 \mathrm{http}: / /$ viminacium.org.rs/arheoloski-park/ (accessed on August 12 ${ }^{\text {th, }}$ 2021). reveals a truly impressive amount of different data. From its homepage, one can follow the link to the "Archaeological park" (“Arheološki park"), to "Viminacium" ("Viminacijum") and to a virtual tour through this Roman city and legionary fort, but he/she can also be informed about exhibitions, projects, a special part of this park dedicated to mammoth remains, as well news related to the site.

On the link entitled "Archaeological park" ("Arheološki park"), visitors can read information about all of the parts of the Viminacium archaeological park. Among them, there are the amphitheatre, the mausoleum and tombs, the baths, the northern gate of the legionary fort, the memoriae and the aqueduct. By clicking on any of these links, the visitor gains access to a short descriptive text about the specific structure and a number of images that show the structure.

On the page entitled "Viminacium" ("Viminacijum"), in Serbian, but also in English, an overview of the site's history is given, both of the city and the legionary fort, together with a history of the research, the chronology, a list of the researchers, panoramic views, images of art and a gallery of old photographs. ${ }^{9}$

The part entitled "Art" ("Umetnost") is certainly the one that is most attractive for archaeologists, since it enables access to specific groups of finds from Viminacium: fresco-painted tombs, glass, pottery, jewellery and coinage. By following any of these links, one reaches basic data about a specific group of finds and also to a number of photographs. The texts are written by experts, but also understandable to the broader public. The same can be said about the photographs.

The next website that was visited by the authors of this paper was that of the National Museum in Belgrade (Narodni muzej u Beogradu, http://www. narodnimuzej.rs). ${ }^{10}$ On the homepage, the visitor is able to inform him/herself about the permanent

$9 \mathrm{http}: / /$ viminacium.org.rs/viminacium/ (accessed on $\mathrm{Au}-$ gust $12^{\text {th, } 2021) .}$

$10 \mathrm{http}: / / w w w . n a r o d n i m u z e j . r s ~\left(a c c e s s e d ~ o n ~ A u g u s t ~ 13^{\text {th }}\right.$, 2021). 


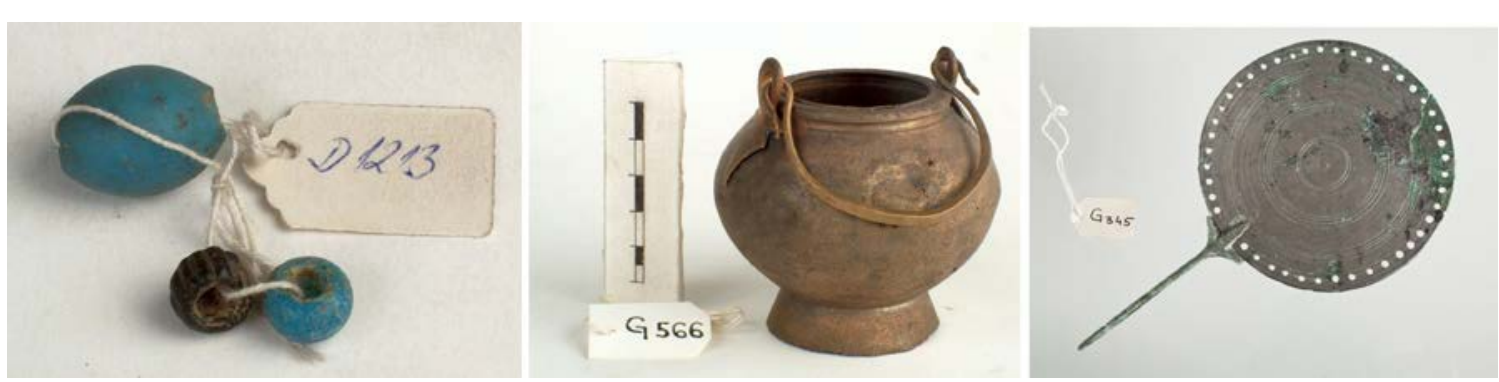

Fig. 10 - Examples of inadequate photographs within the "Collections" of the National museum in Belgrade (accessed August 13th, 2021).

exhibition, the calendar of events, the museum's collections, news, information on the history of the museum as an institution and "learning and fun" ("učenje i zabava"), a section about education workshops for younger visitors. This search can be performed in both Serbian and English.

The section entitled "Collections" ("Zbirke") is the most attractive for archaeologists who browse archaeological finds. Through it, one reaches the pages about collections of finds from pre-history, Antiquity, the Middle Ages and the New Age. In a random search, the authors visited the page dedicated to Antiquity, which offers access to ten links, each of them leading to a specific collection (Hellenistic-Greek collection, the Roman Imperial period, collections of coins from Antiquity and Late Antiquity, etc.). These ten links to collections are accessible only in Serbian, either in Cyrillic or Latin script, while the option in English offers access to only three collections (Greek-Hellenistic collection, collection of epigraphic and anepigraphic monuments, and the collection of coins from Antiquity) ${ }^{11}$ (Fig. 8). In other words, the remaining seven collections do not yet exist in the English version. The user who browses in Serbian can directly access any of the aforementioned ten collections. The user who browses the English version of the site can access the page "Epigraphic and anepigraphic monuments" only if he/she logs in with a username and a password. ${ }^{12}$ (Fig. 9)

$11 \mathrm{http} / /$ www.narodnimuzej.rs/ancient-history/?lang=en (accessed on August 13 ${ }^{\text {th, } 2021)}$

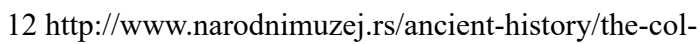
lection-of-roman-and-medieval-epigraphic-anepigraph-
By further browsing of the Antiquity collection, it was realised that it displays expert texts and a number of high quality photographs. However, it was noticed that some inadequate photographs found their way onto the page, while some of them have incorrect captions. (Fig. 10)

As a conclusion regarding the National Museum in Belgrade webpage, it certainly is of high quality, modern and well-structured and it offers a large amount of information about the museum itself and the objects kept therein. A comment remains that the full website is accessible only to those visitors who are fluent in Serbian, while those who browse the site in English are required to $\log$ in and enter a password. In other words, on this website, there is a specific hierarchy in accessing the data.

The Vojvodina museum in Novi Sad (Muzej Vojvodine u Novom Sadu) is the biggest museum in Vojvodina. ${ }^{13}$ On its homepage it is clear that it can be browsed only in Serbian, while the visitor is allowed to choose whether he/she will be reading the content in Cyrillic or Latin script. From this page, the visitor can acquaint themselves with the museum itself, with stories about museum objects and with educational programmes in the museum, and can find directions on how to reach the museum.

By clicking on the "Museum stories" ("Priče iz muzeja") and then on "Stay at home and learn something new" ("Ostani kod kuće i nauči nešto

ic-monuments/?lang=en (accessed on August 13 ${ }^{\text {th }}, 2021$ ). $13 \mathrm{https}$ ://www.muzejvojvodine.org.rs/ (accessed on September $1^{\text {st. }} \underline{\underline{2021}}$ 
СПОМЕНИНИ КУЛТУРЕУ СРЕИНИ

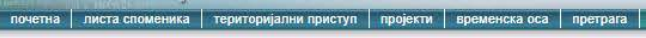

СРЕДЊОВЕКОВНИ ГРАД МАГЛИЧ
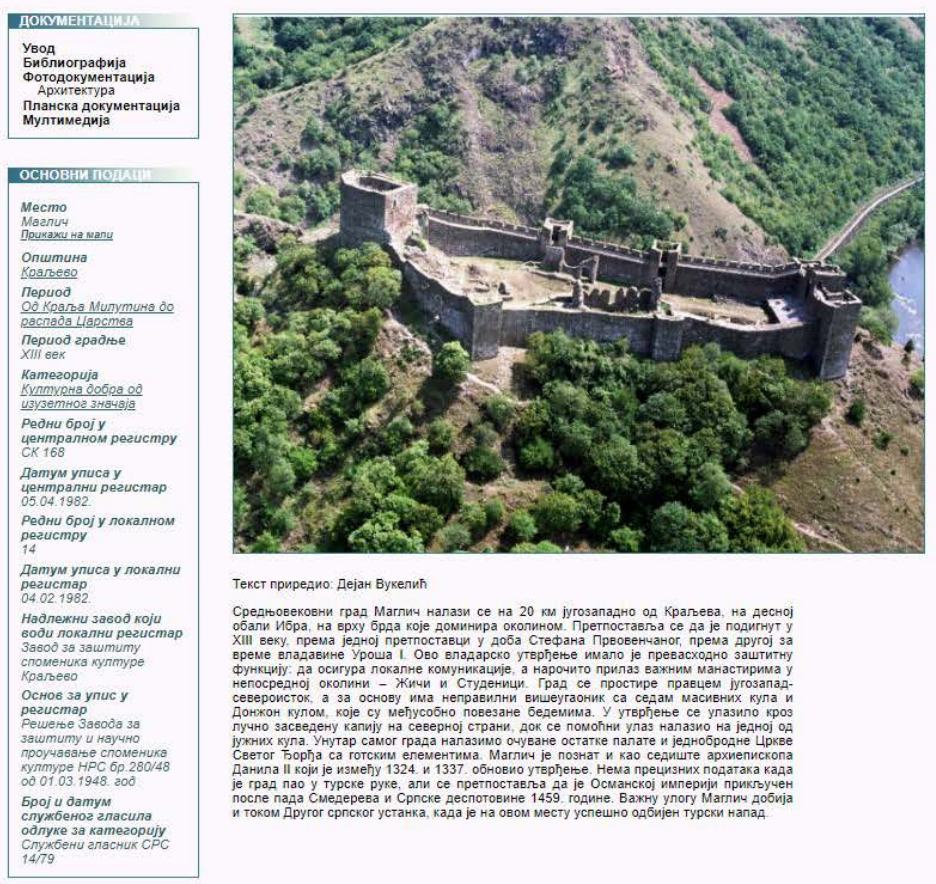

Текст приредио: Дејан Вукелић

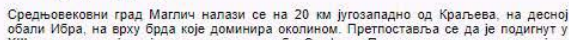

XIII веку. према једној претпоставци у доба Стефана Првовенчаног, према аругоі време владавине Уроша $\perp$ Ово владарско утврђене имало је превасходно заштити

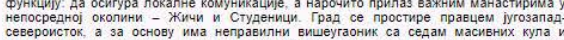

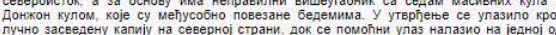
јужних кула Унутар самог града налазимо очуване остатке палате $и$ једнобродне црк

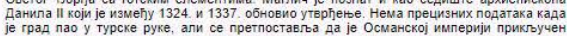

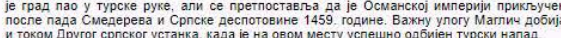

СПОМЕНИЦИ КУЛТУРЕ У СРЕИЈИ

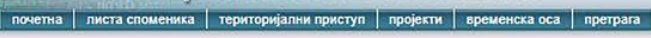

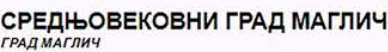

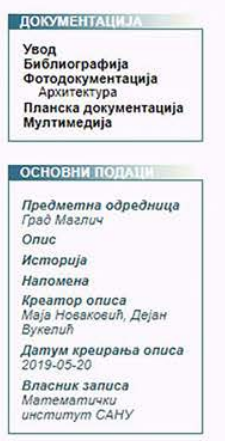

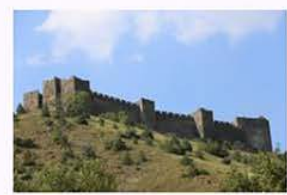

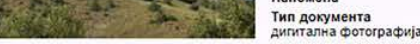
Aaryy apхивирањьa ๑opmar фajin ipg
Pesonyyuja
72 dipi Eoje
millions of colors Ypenjaj ja chusuatte
Canon EOS 60

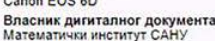

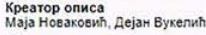

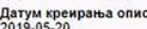

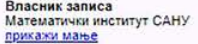
(1)

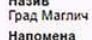

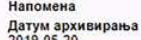
2019.05-20

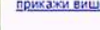

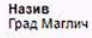
Напомена Aaryna apxnenpasto
2019.05.20

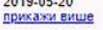

Fig. 11 - Electronic catalogue of Cultural monuments in Serbia (Spomenici kulture u Srbiji) enables public access to basic data about a chosen object (bottom), as well as information collected during research (top)

(accessed July $29^{\text {th }}, 2021$ ). 


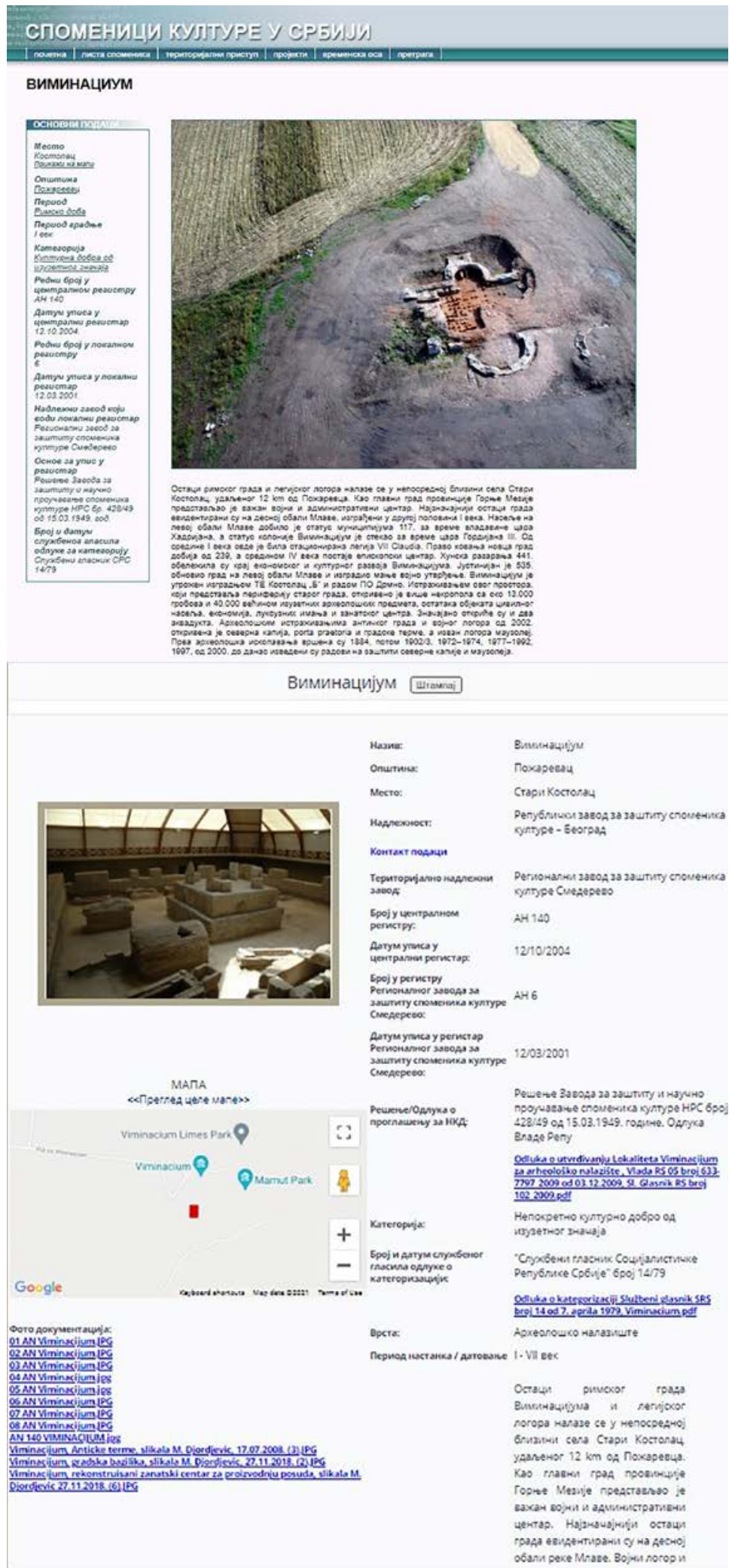

Fig. 12 - Description example of the same cultural object in the electronic catalogue of Cultural monuments in Serbia (Spomenici kulture u Srbiji, top) and in the Information system of immobile cultural objects (Informacioni sistem nepokretnih kulturnih dobara, bottom) (accessed July 30 $\left.{ }^{\text {th }}, 2021\right)$. Although the content is partly duplicated, each description also contains unique information, indicating that they should be linked. 


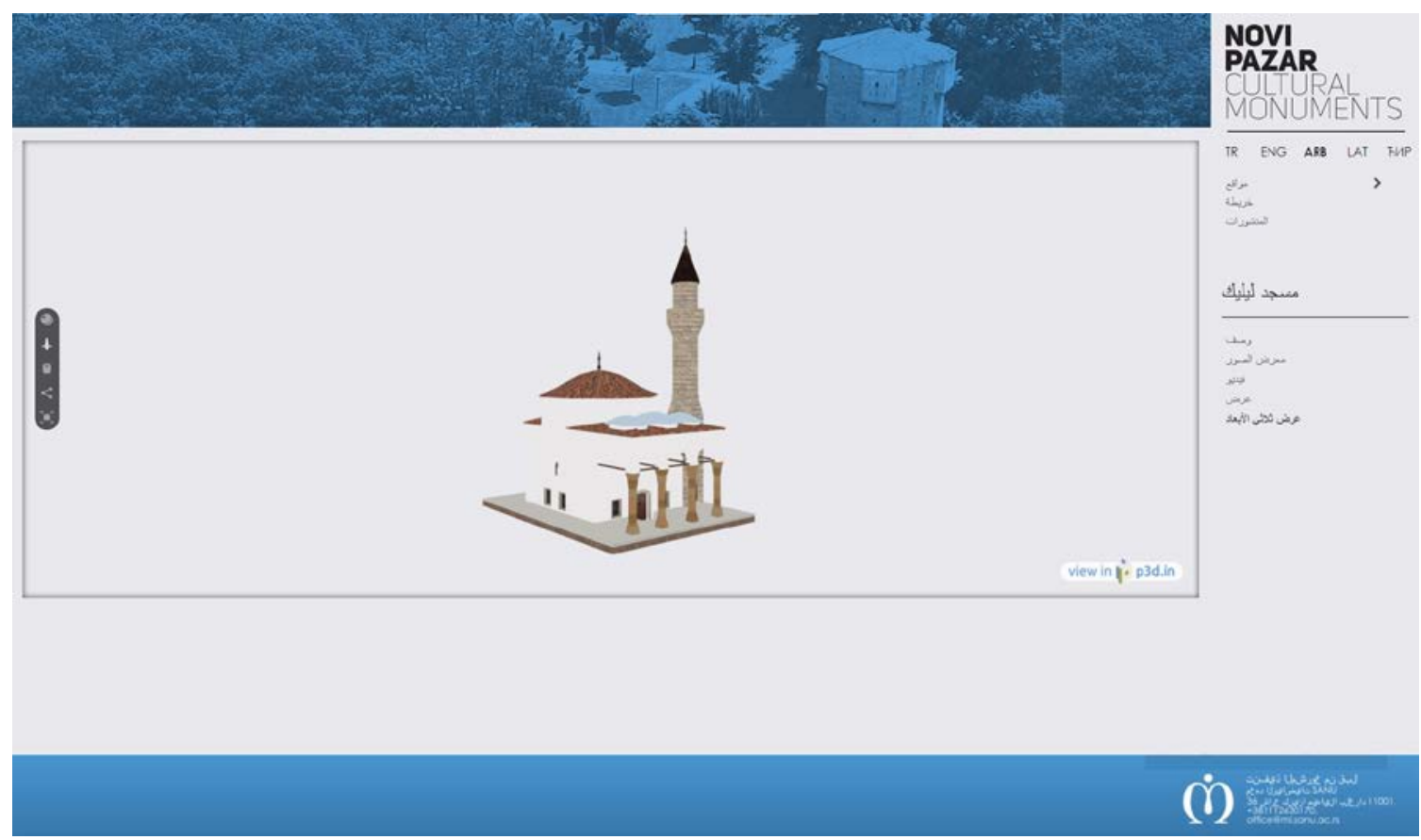

Fig. 13 - Interface in Arabic language and a 3D model of a chosen object of culture without accompanying metadata within the digital guide Novi Pazar - cultural monuments (Novi Pazar - Spomenici kulture) (accessed July $30^{\text {th }}, 2021$ ).

novo") $)^{14}$, a possibility opens for ten stories to be explored, all of them written about museum exhibits. However, only two of them refer to archaeological finds: "A pandemic 2,800 years ago?" ("Epidemija pre 2,800 godina?") about a group grave from Gomolava near Hrtkovci, and "Fish and fishing through history in Vojvodina - or how archaeology considers this question?" ("Ribe i ribolov kroz istoriju u Vojvodini - ili kako arheologija razmišlja o ovom pitanju?"). Obviously, the website is designed in this manner due to the COVID-19 pandemic and the circumstances whereby visitors cannot access the museum physically, but there is no better way for one to gain a better insight into the archaeological collections owned by this museum.

Through the "Museum stories" link ("Priče iz muzeja") there is access to the page entitled "Be responsible to your spirit and body" ("Budi odgovoran prema svom duhu i telu") ${ }^{15}$, a title that certainly does not reveal that under it more stories

$14 \mathrm{https}$ //www.muzejvojvodine.org.rs/category/ostanikod-kuce-i-nauci-nesto-novo/ (accessed on September $1^{\text {st, }}$ 2021).

15https:/www.muzejvojvodine.org.rs/category/budi-odgovoran-prema-duhu-i-telu/ (accessed on September $1^{\text {st }}, 2021$ ). based on archaeological finds are hidden. Among them, there is the "Magic of the Roman glass" ("Magija rimskog stakla"), together with four articles related to archaeobotanics. Since this museum possesses its own space in which it grows its own experimental garden, it is a pity that these papers are not better highlighted and also not accessible to users who are not fluent in Serbian.

Regarding the fact that archaeological collections make up only a part of what is kept at the Museum of Vojvodina, it is clear that they are not the most represented category of this institution's website. A comment remains that maybe (even) more attention should be paid to the archaeobotanical collection, since it is unique not just in Serbia, but in the wider region. It would also be desirable to enable browsing of the website for those who are not fluent in Serbian.

When visiting the website of the National Museum in Niš (Narodni muzej u Nišu, http://narodnimuzejnis.rs) ${ }^{16}$, visitors can inform themselves about basic data related to this museum, about exhibitions, news and events, about museum educa-

16 http://narodnimuzejnis.rs (accessed on September $1^{\text {st. }}$. 2021). 
tion and about publications of the museum. Aside from Serbian (either in Cyrillic or Latin script), the website can also be searched in English or in French.

By entering the page "About the museum" ("O muzeju"), and after that by choosing the "Department of Archaeology" ("Odeljenje arheologije") from the drop-down menu, the user is given a choice of visiting one of the three sub-departments: prehistoric, Ancient or Medieval. ${ }^{17}$ By random choice, the authors of this paper visited the sub-department for prehistory ("Odsek za praistoriju"). ${ }^{18}$ It contains some twenty photographs that are displayed in a circle, as well as a short text about the entire prehistory of Niš and its surroundings. The text is available in Serbian and in French. A similar situation repeats in the remaining two sub-departments, the Ancient and the Medieval one.

Furthermore, by entering the "Exhibitions" ("Izložbe") and then the "Permanent exhibitions" (,Stalne postavke"), users can virtually visit the exhibition space of this museum through some fifty photographs. ${ }^{19}$ The same photographs can be reached through the page "About the museum" ("O muzeju") and then through the drop-down menu, by entering the "Objects" ("Objekti”) and the "Archaeological hall" ("Arheološka sala"). Photographs of the showcases are of medium quality and only some of them clearly show the objects exhibited in them. There are no descriptions, nor explanations of what the user sees in those images.

At the end of this overview, by using reverse methods, the authors tried to reach Serbian websites that display archaeological collections. After typing in some of the keywords (archaeology or archaeological database), the authors concluded that there is not a single link leading to them.

For the purposes of examining the accessibil-

17 https://narodnimuzejnis.rs/o-muzeju/odeljenja/odeljenje-arheologije/ (accessed on September $1^{\text {st, 2021). }}$

$18 \mathrm{http}$ //narodnimuzejnis.rs/o-muzeju/odeljenja/odeljenje-arheologije/odsek-praistorija/?lang=RS (accessed on September $1^{\text {st, } 2021) .}$

$19 \mathrm{https} / /$ narodnimuzejnis.rs/izlozbe/stalnepostavke/?lang=RS (accessed on September $1^{\text {st, 2021). }}$ ity and openness of research data, several digital repositories have been chosen, created from a cooperation between the Mathematical Institute SASA and institutions for protection in Serbia.

An example of such a repository is the electronic catalogue Cultural Monuments in Serbia (Spomenici kulture u Srbiji). It was designed in 2004, as a result of cooperation between the Mathematical Institute SASA, the Institute of Archaeology, the National Library and the Institute for the Protection of Cultural Monuments of the Republic of Serbia (see Spomenici kulture u Srbiji). It represents one of the oldest publicly accessible electronic collections of immobile cultural heritage in the territory of modern Serbia. Besides documentation on about 1,300 cultural monuments (among them also 123 archaeological sites), it also includes results of research projects within the field of digitizing cultural heritage. They, however, include actions undertaken between 2004 and 2014 by the Mathematical Institute with different partner institutions, supported by both international funds (e.g. UNESCO) and national ones (e.g. the Ministry of Culture). In this sense, and besides the standardised description of the object of culture, mostly including some basic text, photographs and metadata about the object, this electronic collection secures public access to specific information collected during field surveys (such as photographs, videos, GPS coordinates and metadata) (Fig. 11). It should be borne in mind that this virtual environment was created fifteen years before legal regulations pertaining to the digitization process in the field of culture in Serbia were created, even before the question of data accessibility and openness arose. This is why it was based on a locally developed infrastructure and standards, while the entirety of the content is protected by copyright or includes ownership rights by a third party. In other words, although the applied scheme of metadata is interoperable and compatible with the most commonly used international standards (Маринковић 2016: 74), at this moment there is no possibility to download 
data without the written approval of the Mathematical Institute. One can say that this electronic collection was one of the earliest test solutions for managing cultural (archaeological) heritage and research data in a digital environment. This is why it needs to be upgraded and adjusted to modern regulations in order for it to follow new trends in managing heritage and link with other national knowledge bases, such as the information system for immobile cultural goods of the Republic Institute for Protection of Cultural Monuments (Informacioni sistem za nepokretna kulturna dobra Republičkog zavoda za zaštitu spomenika kulture (see IS NKD). (Fig. 12)

A somewhat more modern entity is the digital guide Novi Pazar - Cultural Monuments (Novi Pazar - spomenici kulture), developed in 2019 by the Mathematical Institute SASA with the support of the Ministry of Culture and Information of the Republic of Serbia. It is a virtual guide through cultural heritage in south-eastern Serbia, offered in several languages: Serbian, English, Turkish and Arabic (see Novi Pazar - spomenici kulture). At present, it contains documentation about twelve cultural monuments that depict cultural turmoil in the territory of modern Novi Pazar and its surroundings in a chronological frame spanning from the 13th to the $21^{\text {st }}$ century. The documentation created during field surveys in 2019 includes textual descriptions, photographs, videos, panoramic views and 3D images captured using the most recent technology (Fig. 13). However, it does not include metadata, nor information about possibilities of downloading and re-using the data. This is why it would be interesting to link this guide to other national knowledge bases, to enrich the attractively presented content and offer support in further research.

\section{CONCLUSION}

During the late 1990s, in the Republic of Serbia, the earliest attempts to enable access in electronic form to data regarding cultural content, but also to primary research data in the field of social sciences and culture took place. They are mostly connected to the initial attempts of digitizing cultural heritage in Serbia by groups of enthusiasts that at the same time sought freedom in computing i.e. free software, open code and free licenses. However, the majority of representatives of cultural and scientific institutions did not share the same enthusiasm. For example, the results of research conducted in 2012 showed that researchers in the field of social sciences in Serbia are not aware of how useful it is to share research data (Bradić-Martinović 2012). Furthermore, a survey conducted in 2016, which included sixty museums and galleries with museum funding in Serbia, showed that collections in a digital form were accessible only in museums, but not in the internet. Also, preference was given to selective data accessibility rather than to absolute accessibility (Аћимовић 2016: 50). As shown in this paper, under these circumstances and due to the expectations of the EU and the wider world, the government of the Republic of Serbia applied a top-down approach and issued a range of strategies and laws designed to raise awareness about the usefulness of sharing data and to enforce making data accessible, especially that data owned by public institutions. In this paper, the authors try to analyse whether this attempt was fruitful and, if so, to what extent. They were able to conclude that the development dynamics and tendencies in accessing open archaeological databases clearly reflect on the existing databases and that they are also visible on websites of the institutions in charge of defining, protecting and maintaining cultural heritage. However, instead of a model of full accessibility and open data access, the majority still chooses the principle of selective accessibility. The paper shows that one section of the analysed databases and websites is accessible only to users fluent in Serbian. Another part offers the users only a small number of illustrations and poor descriptions of the archaeological material. Some websites even offer a different level of 
accessibility to users fluent in Serbian to that offered to English speakers, asking the latter to enter a username and a password in order to continue browsing. Generally, public access is allowed to descriptive metadata and digital objects described with metadata, but there is no option of downloading data, nor is there information about the possibility of its re-use. Finally, the accessible data is not linked to other existing knowledge bases.

In the future, one should expect the level of accessibility of archaeological databases to rise, both for experts and the broader public. Archaeological research is mostly conducted with money collected through different taxes, which represents an additional reason for its results to be made publicly visible, at least to a certain extent. Recent strategies, rules and initiatives certainly represent a step forward in reaching this goal.

\section{ACKNOWLEDGMENTS}

We are particularly grateful to the following initiatives, which inspired the research: COST Action CA18128 - Saving European Archaeology from the Digital Dark Age (SEADDA); the LiSeH Spring School 2020/2021: Linked Data \& the Semantic Web for Humanities Research, co-organised by the Austrian Centre for Digital Humanities and Cultural Heritage at the Austrian Academy of Sciences; and the Centre for Information Modelling - Austrian Centre for Digital Humanities at the University of Graz, which is funded by CLARIAH-AT and supported by the $\mathrm{H} 2020$ project ELEXIS.

\section{BIBLIOGRAPHY}

Аћимовић, М. 2016

Анкета о доступности фото-документације музеја у Србији, у: Отворени приступ музејској документацији $y$ Србији: искуства, изазови и потенцијали, М. Стијовић (изд.), Београд: Централни институт за конзервацију, 43 - 52.

\section{(Aćimović, M. 2016}

Anketa o dostupnosti foto-dokumentacije muzeja u Srbiji, u: Otvoreni pristup muzejskoj dokumentaciji u Srbiji: iskusta, izazovi i potencijali, M. Stijović (izd.), Beograd: Centralni institut za konzervaciju, 43-52).

Berlin Declaration on Open Access to Knowledge in the Sciences and Humanities (published October $\left.22^{\text {nd }}, 2003\right)$. https://openaccess.mpg.de/Berlin-Declaration. (accessed July 22 ${ }^{\text {nd }}, 2021$ ).

\section{Bradic-Martinovic A., Zdravkovic, A. 2012}

Integration of western Balkan countries into the European system of digital data archives in social sciences: the case of Serbia. Review of Applied Socio-Economic Research, 4(2): 32-41.

Брадић-Мартиновић, А. 2021

Архивирање и управљање подацима $y$ друштвеним наукама - најбоља пракса. Вебинар одржан 15. јуна 2021. на Математичком институту САНУ.

\section{(Bradić-Martinović, A.}

2021. Arhiviranje i upravljanje podacima u društvenim naukama - najbolja praksa. Webinar held at the Mathematical Institute SASA.

https://miteam.mi.sanu.ac.rs/asset/x5PQQF8HJTJmCHttn. (accessed July 26 $6^{\text {th }}, 2021$ ).

VIAF. http://viaf.org/. (accessed July $16^{\text {th }}, 2021$ ).

\section{Вуликић, Н. 2020}

Употреба ИКТ у установама културе.

(Vulikić, N. 2020, Upotreba IKT u ustanovama kulture).

https://prezi.com/yxvqgmgpv6_v/presentation/. (accessed July $19^{\text {th }}, 2021$ ).

G8 Open Data Charter and Technical Annex (published June $\left.18^{\text {th }}, 2013\right)$. https://www.gov.uk/government/publications/open-data-charter/g8-opendata-charter-and-technical-annex. (accessed June $\left.22^{\text {nd }}, 2021\right)$. 
Global Open Data Index. https://index.okfn.org/ place/. (accessed July $13^{\text {th }}, 2021$ ).

Guidelines to the Rules on Open Access to Scientific Publications and Open Access to Research Data in Horizon 2020, version 3.2 (published March 21 ${ }^{\text {st }}$, 2021). https://ec.europa.eu/research/ participants/data/ref/h2020/grants_manual/hi/oa pilot/h2020-hi-oa-pilot-guide_en.pdf. (accessed June $22^{\text {nd }}, 2021$ ).

data.europa.eu. https://data.europa.eu/en. (accessed July $20^{\text {th }}, 2021$ ).

data.gov. https://www.data.gov/. (accessed July $\left.20^{\text {th }}, 2021\right)$.

DCS - Data Centar Srbije za društvene nauke. https://datacentarserbia.com/. (accessed July $26^{\text {th }}$, 2021).

Directive 2003/98/EC of the European Parliament and of the Council of 17 November 2003 on the re-use of public sector information. https://eurlex.europa.eu/legal-content/en/ALL/?uri=CELEX\%3A32003L0098. (accessed July 12 ${ }^{\text {th }}, 2021$ ).

Directive 2013/37/EU of the European Parliament and of the Council of 26 June 2013 amending Directive 2003/98/EC on the re-use of public sector information Text with EEA relevance. https://eurlex.europa.eu/legal-content/EN/ALL/?uri=CELEX:32013L0037. (accessed July 12 ${ }^{\text {th }}, 2021$ ).

EUROPEANA. https://www.europeana.eu/. (accessed July $20^{\text {th }}, 2021$ ).

Закон о архивској грађи и архивској делатности. Службени гласник РС, 6/2020.

Zakon o arhivskoj građi i arhivskoj delatnosti. Službeni glasnik RS, 6/2020.

https://www.pravno-informacioni-sistem.rs/ SlGlasnikPortal/eli/rep/sgrs/skupstina/zakon/2020/6/7/reg. (accessed July 14 ${ }^{\text {th }}, 2021$ ).
Закон о ауторским и сродним правима. Службени гласник РС, 104/2009.

Zakon o autorskim i srodnim pravima. Službeni glasnik RS, 104/2009.

http://www.pravno-informacioni-sistem.rs/ S1GlasnikPortal/eli/rep/sgrs/skupstina/zakon/2009/104/30/reg/20190926. (accessed July $\left.14^{\text {th }}, 2021\right)$.

Закон о електронској управи. Службени гласник РС, 27/2018.

Zakon o elektronskoj upravi. Službeni glasnik RS, 27/2018.

https://www.pravno-informacioni-sistem.rs/ SlGlasnikPortal/eli/rep/sgrs/skupstina/zakon/2018/27/4/reg. (accessed July 12 ${ }^{\text {th }}, 2021$ ).

Закон о заштити података о личности. Службени гласник РС, 87/2018.

Zakon o zaštiti podataka o ličnosti. Službeni glasnik RS, 87/2018.

http://www.pravno-informacioni-sistem.rs/ SlGlasnikPortal/eli/rep/sgrs/skupstina/zakon/2018/87/13/reg. (accessed July 14 $4^{\text {th }}, 2021$ ).

Закон о култури. Службени гласник РС, 72/2009, 6/2020.

Zakon o kulturi. Službeni glasnik RS, 72/200, 6/2020.

http://www.pravno-informacioni-sistem.rs/ SlGlasnikPortal/eli/rep/sgrs/skupstina/zakon/2009/72/1/reg. (accessed July $13^{\text {th }}, 2021$ ).

Закон о науци и истраживањима. Службени гласник РС, 49/2019.

Zakon o nauci i istraživanjima. Službeni glasnik $R S, 49 / 2019$.

https://www.pravno-informacioni-sistem.rs/ SlGlasnikPortal/eli/rep/sgrs/skupstina/zakon/2019/49/1. (accessed July $21^{\text {st }}, 2021$ ).

ИС НКД - Информациони систем непокретног културног наслеђа.

IS NKD - Informacioni sistem nepokretnog kul- 
turnog nasleđa.

https://nasledje.gov.rs/index.cfm/index/index. (accessed July 30 ${ }^{\text {th }}, 2021$ ).

Листа стандарда интероперабилности, верзија 2.1 .

Lista standarda interoperabilnosti, version 2.1 . https://www.ite.gov.rs/extfile/sr/2002/LISTA

STANDARDA_Tehnicke_Interoperabilnosti\%20 v\%202.1c.pdf. (accessed July 14 ${ }^{\text {th }}, 2021$ ).

\section{Маринковић, Б. 2016}

Смернице за формат метаподатака за описивање културне баштине и начине њиховог очувања, y: Отворени приступ музејској документацији $y$ Србији: искуства, изазови $u$ потенцијали, (ур.) М. Стијовић, Београд: Централни институт за конзервацију, 61-77.

(Marinković, B. 2016

Smernice za format metapodataka za opisivanje kulturne baštine i načine njihovog očuvanja, u: Otvoreni pristup muzejskoj dokumentaciji u Srbiji: iskustva, izazovi i potencijali, (ur.) M. Stijović, Beograd: Centralni institut za konzervaciju, 61-77).

НаРДуС - Национални Репозиторијум Дисертација у Србији.

NaRDuS - Nacionalni Repozitorijum Disertacija u Srbiji.

https://nardus.mpn.gov.rs (accessed September $\left.13^{\text {th }}, 2021\right)$.

Нови Пазар - споменици културе.

Novi Pazar - spomenici kulture.

http://novipazarspomenici.mi.sanu.ac.rs/. (accessed July $28^{\text {th }}, 2021$ ).

Objedinjeni portal za pretragu kulturnog nasleđa Srbije (published May 26 ${ }^{\text {th }}, 2019$ ). http://rtv.rs/ sr_lat/kultura/objedinjeni-portal-za-pretragu-kulturnog-nasledja-srbije_1020397.html. (accessed July $20^{\text {th }}, 2021$ ).

OpenRefine. https://openrefine.org/. (accessed
July $\left.16^{\text {th }}, 2021\right)$.

Платформа за отворену науку (усвојена 09. јула 2018).

Platforma za otvorenu nauku (accepted July 9 ${ }^{\text {th }}$, 2018).

http://www.mpn.gov.rs/wp-content/up-

loads/2018/07/Platforma-za-otvorenu-nauku.pdf. (accessed July 22 $2^{\text {nd }}, 2021$ ).

Портал отворене науке.

Portal otvorene nauke.

https://www.open.ac.rs/. (accessed July 22 nd, 2021).

Портал отворених података.

Portal otvorenih podataka.

https://data.gov.rs/. (accessed July 14 ${ }^{\text {th }}, 2021$ ).

ПОУ Србија - Партнерство за Отворену Управу.

POU Srbija - Partnerstvo za Otvorenu Upravu. https://ogp.rs/. (accessed July 12 $2^{\text {th }}, 2021$ ).

Правилник о ближим условима за дигитализацију културног наслеђа. Службени гласник РС, 76/2018.

Pravilnik o bližim uslovima za digitalizaciju kulturnog nasleđa. Službeni glasnik RS, 76/2018.

https://www.pravno-informacioni-sistem.rs/S1GlasnikPortal/eli/rep/sgrs/ministarstva/pravilnik/2018/76/2/reg. (accessed July 13 ${ }^{\text {th }}, 2021$ ).

Претраживач културног наслеђа.

Pretraživač kulturnog nasleđa.

https://kultura.rs/. (accessed July $14^{\text {th }}, 2021$ ).

Програм развоја електронске управе у Републици Србији за период од 2020. до 2022. године са Акционим планом за његово спровођење. Службени гласник РС, 85/2020. Program razvoja elektronske uprave u Republici Srbiji za period od 2020. do 2022. godine sa Akcionim planom za njegovo sprovođenje. Službeni 
glasnik RS, 85/2020.

https://www.pravno-informacioni-sistem.

rs/SlGlasnikPortal/eli/rep/sgrs/vlada/dru-

giakt/2020/85/1/reg. (accessed July $13^{\text {th }}, 2021$ )

RCUB - Računarski centar Univerziteta u Beogradu. https://www.rcub.bg.ac.rs/. (accessed July $\left.26^{\text {th }}, 2021\right)$.

Smederevac, S., Pajić, D., Radovanović, S., Ghilezan, S., Čolović, P., Milosavljević, B. 2020. Otvorena nauka: praksa i perspektive. Novi Sad: Univerzitet u Novom Sadu.

Смернице за дигитализацију културног наслеђа РС (септембар 2017).

Smernice za digitalizaciju kulturnog nasleđa RS (septembar 2017).

https://www.kultura.gov.rs/extfile/sr/205/smernice-za-digitalizaciju-kulturnog-nasledja-u-republici-srbiji.pdf. (accessed July 14 ${ }^{\text {th }}, 2021$ ).

Споменици културе у Србији.

Spomenici kulture u Srbiji.

http://spomenicikulture.mi.sanu.ac.rs/. (accessed July $29^{\text {th }}, 2021$ )

Стратегија научног и технолошког развоја Републике Србије за период од 2016. до 2020. године - Истраживања за иновације. Службени гласник РС, 25/2016.

Strategija naučnog i tehnološkog razvoja Republike Srbije od 2016. do 2020. godine - Istraživanja za inovacije. Službeni glasnik RS, 25/2016.

https://www.pravno-informacioni-sistem.rs/ S1GlasnikPortal/eli/rep/sgrs/vlada/strategija/2016/25/1. (accessed July 22 $2^{\text {nd }}, 2021$ ).

Стратегија научног и технолошког развоја Републике Србије за период од 2021. до 2025. године „Моћ знања”. Службени гласник РС, $10 / 2021$.

Strategija naučnog i tehnološkog razvoja Republike Srbije za period od 2021. do 2025. godine „Moć znanja“. Službeni glasnik RS, 10/2021. http://www.pravno-informacioni-sistem.rs/ SlGlasnikPortal/eli/rep/sgrs/vlada/strategija/2021/10/1/reg. (accessed July 22 $2^{\text {nd }}, 2021$ ).

Стратегија развоја електронске управе у Републици Србији за период 2015-2018. године и Акциони план за спровођење Стратегије за период 2015-2016. године. Службени гласник PC, 107/2015.

Strategija razvoja elektronske uprave u Republici Srbiji za period 2015-2018. godine i Akcioni plan za sprovođenje Strategije za period 2015-2016. godine. Službeni glasnik RS, 107/2015.

https://www.pravno-informacioni-sistem.rs/ SlGlasnikPortal/eli/rep/sgrs/vlada/strategija/2015/107/1/reg. (accessed July 12 ${ }^{\text {th }}$, 2021).

Šegan-Radonjić, M., Tapavički-Ilić, M. 2021. Digitisation and Data Management of Archaeological Heritage in Serbia (1991-2020). Internet Archaeology, 58. doi: 10.11141/ia.58.15.

Уредба о начину рада Портала отворених података. Службени гласник РС, 104/2018.

Uredba o načinu rada Portala otvorenih podataka. Službeni glasnik RS, 104/2018.

http://www.pravno-informacioni-sistem. rs/SlGlasnikPortal/eli/rep/sgrs/vlada/uredba/2018/104/4/reg. (accessed July 12 ${ }^{\text {th }}, 2021$ ).

Фонд за науку Републике Србије.

Fond za nauku Republike Srbije.

http://fondzanauku.gov.rs/. (accessed July 23 ${ }^{\text {rd }}$, 2021).

Церовић, И., Кривокапић, Ђ., Милошевић, Ф. 2019. Водич кроз отворене податке. Београд: ДУМ Адвертисинг.

Cerović, I., Krivokapić, Đ., Milošević, F. 2019. Vodič kroz otvorene podatke. Beograd: DUM Advertising.

https://www.rs.undp.org/content/dam/serbia/Publications $\% 20$ and $\% 20$ reports/Vodic\%20kroz $\% 20$ 
otvorene\%20podatke_serbian.pdf. (accessed July $\left.12^{\text {th }}, 2021\right)$.

Wikidata. https://www.wikidata.org/wiki/Wikidata:Main_Page. (accessed July 16 $6^{\text {th }}, 2021$ ).

\section{REZIME \\ RAZVOJ I SADRŽAJ ARHEOLOŠ- KIH BAZA PODATAKA U SRBIJI}

\section{KLJUČNE REČI: PODACI, ČUVANJE PODATA- KA, SRBIJA, ARHEOLOGIJA, BAZA PODATAKA.}

Usled pandemije COVID-19, tokom protekle godine se u celom svetu osetila nejednakost u različitim zemljama i društvima. Između ostalog, ova nejednakost se odnosila, a odnosi se još uvek, na pristup arheološkim podacima, kako fizički, tako i digitalno. Ljudi koji stvaraju arheološke baze podataka, kao i korisnici ovakvih baza, proveli su mnogo vremena radeći od svojih kuća, daleko od samih arheoloških nalaza i istraživačkih podataka. Sa druge strane, ovo je bio pravi trenutak da se spozna važnost toga da podaci postanu otvoreni i svima dostupni, kako na nacionalnom, tako i na međunarodnom nivou.

Autorke ovog priloga su zato odlučile da naprave pregled baza podataka iz različitih ustanova u čijoj su nadležnosti očuvanje i zaštita kulturnog nasleđa, sa ciljem da sagledaju njihova pravila koja se odnose na pristupačnost i upotrebu podataka kojima raspolažu. Ovaj proces je bio jednostavan i podrazumevao je posetu određenim veb-sajtovima ili bazama podataka. Pregledani su obim i sadržaj, ali i značaj predstavljenog arheološkog nasleđa. Nakon toga, autorke su procenjivale da li je nasleđe klasifikovano i opisano na zadovoljavajući način, kao i da li su ovi podaci dostupni na nekom stranom jeziku.

Bilo je potrebno steći uvid u to da li je moguće pristupiti digitalnim objektima (dokumentima i pripadajućim meta-podacima), da li je pristup omogućen svim korisnicima ili postoji određena hijerarhija, koja su pravila korišćenja, ponovne upotrebe i distribucije itd.

Nakon posete određenom broju veb-sajtova, autorke su sakupilo dovoljnu količinu da izvedu određene zaključke u vezi sa pristupačnošću i upotrebljivošću podataka o arheološkim veb bazama u Srbiji. Ustanovljeno je da, umesto modela potpune pristupačnosti i otvorenosti podacima, većina institutcija pribegava principu selektivne pristupačnosti. Deo ovde obrađenih baza podataka i veb-stranica pristupačan je samo korisnicima koji se služe srpskim jezikom, dok drugi nude samo mali broj ilustracija i šture opise arheološkog materijala. Neke veb-stranice čak predviđaju različite nivoe pristupačnosti za korisnike koji se služe srpskim i za one koji se služe npr. engleskim jezikom. Uopšteno gleajući, omogućen je javni pristup deskriptivnim meta-podacima i digitalnim objektima opisanim u okviru meta-podataka, ali ne postoji mogućnost da se podaci preuzmu, niti postoje informacije o njihovom ponovnom preuzimanju. Najzad, pristupačni podaci nisu povezani ni sa jednom postojećom bazom znanja.

$* * *$

Arheologija i prirodne nauke (Archaeology and Science) is an Open Access Journal. All articles can be downloaded free of charge and used in accordance with the licence Creative Commons - Attribution-NonCommercial-NoDerivs 3.0 Serbia (https://creativecommons.org/licenses/bync-nd/3.0/rs/.

Časopis Arheologija i prirodne nauke je dostupan u režimu otvorenog pristupa. Članci objavljeni u časopisu mogu se besplatno preuzeti sa sajta $i$ koristiti u skladu sa licencom Creative Commons - Autorstvo-Nekomercijalno-Bez prerada 3.0 Srbija (https://creativecommons.org/licenses/bync-nd/3.0/rs/. 